\title{
National Academy of Medicine of Mexico position in favor of regulating the use of stem cells and human embryos for therapeutic or experimental purposes other than clinical protocols approved by the National Health System
}

\author{
Armando Mansilla-Olivares, ${ }^{1}$ Julieta Rojo, ${ }^{1}$ María de Jesús Medina, ${ }^{2}$ Fermín Valenzuela-Gómez-Gallardo, ${ }^{1}$ \\ Joaquín López-Bárcena, ${ }^{1}$ Fernando Meneses-González, ${ }^{1}$ ván Velazco, ${ }^{3}$ Héctor Mayani-Viveros, ${ }^{4}$ and \\ José Ignacio Santos-Preciado ${ }^{1}$ \\ ${ }^{1}$ Academia Nacional de Medicina de México, Committee of Liaison and Dissemination of Knowledge; ${ }^{2}$ Universidad Nacional Autónoma de México, \\ Institute of Research on Law; ${ }^{3}$ Sociedad Mexicana para la Investigacion de Células Troncales; ${ }^{4}$ Instituto Mexicano del Seguro Social, Department \\ of Oncology Research, Ciudad de México, Mexico
}

\begin{abstract}
In recent years, the use of stem cells for therapeutic purposes has received attention from research groups. In Mexico, the Mexican Official Standard 260-SSAI-2015 regarding the use of stem and progenitor cells for therapeutic and research purposes is in the process of authorization. Even when this has not been approved, an increasing number of establishments are offering medical services involving the use of stem cells for therapeutic purposes without official regulatory authorization. The Mexican Academy of Medicine of Mexico makes its position public in favor of regulating the use of stem cells and embryos for therapeutic and research purposes.
\end{abstract}

KEY WORDS: Stem cell transplant. Health service establishments. Stem cells. Embryos.

\section{Rationale}

Given the importance for public health and in order to contribute to the advance of medical sciences in Mexico through processes of proven effectiveness and with the purpose to guarantee the correct use of therapeutic resources in the Mexican population, as well as to avoid misuse and proliferation of interventions that have no scientific-medical support, the National Academy of Medicine of Mexico, as an advisory body of the federal government, proposes the generation of the regulatory framework for stem cells and germinal cells management, prescription, scientific evaluation of their use and health surveillance, to which establishments and service providers that perform these treatments throughout the national territory should be subjected, based on the following recitals:
1. It is necessary for treatments with stem cells to be regulated in order to ensure that health services offered in the form of medical tourism are based on protocols and prescription standards that guarantee their quality as well as patient safety and, additionally, contribute to scientific knowledge on the subject.

As a result of health globalization, "medical tourism" or "health tourism", an activity that is considered an expression of private medical trade ${ }^{1,2}$ that offers unregulated therapies with stem cells known as "stem cell treatment medical tourism", appeared on the international scene..$^{1-3}$

Owing to the increase of medical units that offer this type of therapies, as well as of health professionals that participate therein, more legal certainty is required in decision making for the classification of diseases, therapeutic moments and patients susceptible to benefit from stem cell management through
Correspondence: Armando Mansilla-Olivares E-mail: armanolnc@gmail.com
Date of reception: 02-10-2018

Date of acceptance: 04-10-2018

DOI: 10.24875/GMM.M19000218
Gac Med Mex. 2018;154:625-627

Contents available at PubMed www.gacetamedicademexico.com 
mechanisms agreed upon by experts in the medical area and approved regulatory authorities, in order to support their safety and efficacy in our country and thereby generate better practices and evidence to contribute to international regulation on the subject.

While the General Statute of Law and its associated regulations explicitly prohibit the marketing of human cells and tissues, as well as their components (articles 315 to 327), in general and particular terms it points out that therapeutic procedures that require stem cells should be free, and it is therefore essential to specify the regulation on the matter that is granted through medical tourism health services.

2. It is essential for experimental procedures for treatments with stem cells to be regulated in order to ensure patient safety and contribute to the generation of scientific evidence within the framework of regulation in health research matters.

The General Statute Health, in articles 315 and 341 and associated regulations require for establishments and service providers, as well as those who perform experimental procedures with therapeutic purposes, to have the respective authorizations. In order to specify the handling regarding stem cells, the Official Mexican Standard 260-SSA1-2015 Project was created, for the use of stem and progenitor cells for therapeutic and research purposes, still under review process by COFEPRIS, as well as the General Statute of Health Regulations in Matters of Blood and Stem Cells Derivation for Therapeutic and Investigational Use, under review by the Legal Affairs and Human Rights areas of the Ministry of Health.

However, procedures are currently offered that, due to the lack of scientific support fall in the experimental field, are easily available and commercialized throughout Mexico and expose the safety of users, which makes the issuance of a specific legislation indispensable in order to prevent "indirect" stem cell marketing practices from continuing, alluding to the costs for their handling, preservation and application. Additionally, these guidelines will favor for therapeutic procedures with the use of stem cells to be carried out following a protocol in compliance with article 342 bis 2 and the General Statute of Health Regulations in Matters of Research on Human Beings and to contribute to the generation of scientific knowledge, thus avoiding a negative impact on local scientific development and on societal health status. ${ }^{4,5}$

3. It is necessary for the National Academy of Medicine of Mexico, together with the Ministry of Health, to open a nation-wide, formal space to resume scientific, ethical and legal analysis on the final destination of human embryos produced by assisted reproductive technologies.

Beyond scientific, ethical or religious discussions regarding the scope of assisted reproduction, the need to regulate the manipulation of embryos that are generated by these technologies is internationally recognized, in order to have objective criteria for the use and destination of these biological products, as well as for the final use of cryopreserved "leftover" embryos that for different reasons are no longer usable for the primary purpose they were developed for and taking into account Dr. Yamanaka's development, pluripotent activity potential, in order for the reprogramming of mature somatic cells into pluripotent stem cells to be carried out and subsequently generate differentiated cells and transplant them to the same individual they were extracted from.

The General Statute of Health and its secondary regulations does not consider the use of human embryos for research and there are no guidelines for the potential application of cells generated from human pluripotent cells, a void that started being filled with the initiative of the Decree Project that creates the General Law of Human Assisted Reproduction, the final approach for approval of which has not materialized.

Based on the foregoing, the National Academy of Medicine of Mexico proposes to the Federal Ministry of Health:

A. To support the procedures to expedite the approval of Official Mexican Standard 260-SSA12015 , for the use of stem and progenitor cells for therapeutic and research purposes and the General Statute of Health Regulations in Matters of Blood and Stem Cells Derivation for Therapeutic and Investigational Use, in order to ensure the correct development and implementation of treatments with stem cells with due scientific support, applicable to all establishments and providers that offer or promote treatments based on stem and germ cells.

B. To support the performance of a comparative study on legislations related to research with human embryos and their possible application to pluripotent stem cells, differentiated into clinically relevant phenotypes, and this way promote the discussion and regulation of these procedures taking into consideration that there are universal ethics standards that are applicable to scientific 
research, both for basic science and biomedicine clinical practice. ${ }^{5}$

C. That the construction and issuance of this new specific regulatory framework should take into account international standards and recommendations of various scientific associations, such as the Ibero-American Donation and Transplantation Network/Council ${ }^{6}$ or the International Society for Stem Cell Research, ${ }^{7}$ which have proposed ethical and regulatory guidelines in order for stem cells to be regarded as biological products rather than medical devices.

\section{References}

1. Hopkins L, Labonté R, Runnels V, Packer C. Medical tourism today: what is the state of existing knowledge? J Public Health Policy. 2010;31:185-198.

2. Kawachi IO, Wamala SP. Globalization and Health. EE. UU.: Oxford University Press; 2007.

3. Zarzeczny A, Caulfield T. Stem cell tourism and doctors' duties to minors: a view from Canada. Am J Bioeth. 2010;20:3-15.

4. Reardon S. Mexico proposal to ban human-embryo research would stifle science. Nature. 2016;540:180.

5. Sipp D, Pei D. Bioethics in China: no wild east. Nature. 2016;534:465-467.

6. Consejo Iberoamericano de Donación y Trasplante. Declaración de Quito sobre terapias celulares sin evidencia demostrada. Ecuador: Consejo Iberoamericano de Donación y Trasplante; 2012.

7. International Society for Stem Cell Research. Guidelines for stem cell research and clinical translation. EE. UU.: International Society for Stem Cell Research; 2016. 